

\section{DISCLAIMER}

This report was prepared as an account of work sponsored by an agency of the United States Government. Neither the United States Government nor any agency Thereof, nor any of their employees, makes any warranty, express or implied, or assumes any legal liability or responsibility for the accuracy, completeness, or usefulness of any information, apparatus, product, or process disclosed, or represents that its use would not infringe privately owned rights. Reference herein to any specific commercial product, process, or service by trade name, trademark, manufacturer, or otherwise does not necessarily constitute or imply its endorsement, recommendation, or favoring by the United States Government or any agency thereof. The views and opinions of authors expressed herein do not necessarily state or reflect those of the United States Government or any agency thereof. 


\section{DISCLAIMER}

Portions of this document may be illegible in electronic image products. Images are produced from the best available original document. 


\section{DISCLAIMER}

This book was prepared as an account of work sponsored by an agency of the United States Government. Neither the United States Government nor any agency thereof, nor any of their employees, makes any warranty, express or implied, or assumes any legal liability or responsibility for the accuracy, completeness, or usefulness of any information, apparatus, product or process disciosed, or represents that its use would not infringe privately owned rights. References herein to any specific commercial product, process, or service by trade name, trademark, manufacturer, or otherwise, does not necessarily constitute or imply its endorsement, recommendation, or favoring by the United States Government or any agency thereof. The views and opinions of authors expressed herein do not necessarily state or reflect those of the United States Government or any agency thereof. 
EGG-GTH- 5739

DE82 012202

\title{
GEOTHERMAL DEICING OF HIGHWAYS \\ AND BRIDGE STRUCTURES
}

Ivar A. Engen

Published February 1982

EG\&G Idaho, Inc. Idaho Falls, Idaho 83415

\author{
Prepared for the \\ U.S. Department of Energy \\ Idaho Operations Office \\ Under DOE Contract No. DE-AC07-76ID01570
}

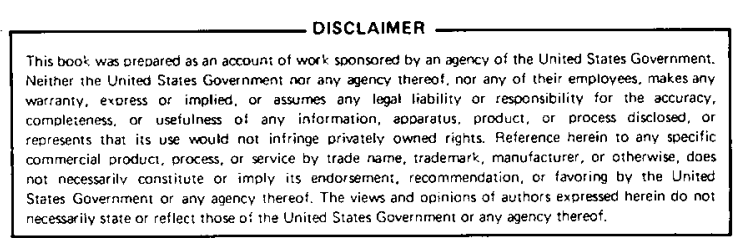

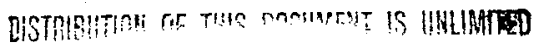

Mow 


\section{ABS TRACT}

This report presents preliminary cost estimates prepared for the Colorado Department of Highways regarding deicing of highways and bridge structures. 


\section{FOREWORD}

The Geothermal Technical Ass istance Program was developed under the premise that the majority of groups or individuals with available geothermal resources do not have the experience or manpower necessary to do a preliminary engineering and economic feasibility evaluation for geothermal energy projects. In order to disseminate technical information and to facilitate expanded use of geothermal energy resources, ass istance was provided through FY-1981 in a consulting format on a first-come, staff-and-funds-available basis. Technical ass istance can relate to conceptualization; engineering; economics; water chemistry implications for environmental, disposal, and material selection considerations; and planning and development strategies. This report is one of a series adapted from consultation provided to requesters either through in-house efforts or through limited efforts subcontracted to local engineering firms. The Geothermal Technical Assistance (GTA) reports in this series, which are listed below, will be available early in 1982 to those with interest in specific geothermal applications.

\section{GTA EG\&G}

Report No. Report No. Title

1. EGG-GTH-5512 Aquaculture Facility Potential at Boulder Hot

2. EGG-GTH-5521 Prel iminary Geothermal Disposal Cons iderations, State Health Laboratory, Bo ise, Idaho

3. EGG-GTH-5573 Geothermal Conversion at Veterans Hospital, Boise, Idaho

4. EGG-GTH-5574 Geothermal Applications for Highway Rest Areas

5. EGG-GTH-5575 Geothermal Applications for a Tannery

6. EGG-GTH-5599 Prel iminary Conceptual Design for Geothermal Space Heating Conversion of Schoot. District 50 Joint Facilities at Pagosa Springs, Cotorado

7. EGG-GTH-5617 Selected Geothermal Technical Ass istance Efforts Comprising short descriptions of ten space heating projects; five district heating projects, and three heat exchanger projects) 
GTA

EG\&G

Report No. Report No.

Title

8. $\quad E G G-2137$

Geothermal Source Potential and Utilization for

Methane Generation and Alcohol Production (subcontractor report)

9. $E G G-2138$

Geothermal Source Potential and Utilization for Alcohol Production (subcontractor report)

10. EGG-2139

Potential Geothermal Energy Applications for Tdaho Elks Rehabilitation Hospital

(subcontractor report)

11. EGG-2144 Technical Assistance Report on a Geothermal Heating Utility for Lemmon, South Dakota (subcontractor report)

12. $E G G-21.45$

Economic Analysis for Utilization of Geothermal Energy by North Dakot a Concrete Products Company (subcontractor report)

13. EGG-2146

Geothermal Feasibility Analys is II for Polo School District No. 29-2, South Dakota (subcontractor report)

14. $E G G-2147$

Preliminary Feasibility Study of Heating and. Cooling Alternatives for Nebraska Western College, Scottsbluff, Nebraska (subcontractor report)

15. $E G G-2148$

Inventory of Thermal Springs and Wells Within a One-Mjle Radius of Yucca Lodge, Truth or Consequences, New Mexico (subcontractor report)

16. EGG-2149 Space Heating for Spa Facilities at 0 jo Caliente, New Mexico (subcontractor report)

17. EGG-2150

Geothermal Heated Office Building at Glenwood Springs, Colorado (subcontractor report)

18. $E G G-215$

Final Report--Dickinson Geothermal Study, Dickinson, North Dakota (subcontractor report)

19. EGG-2152 Cancelled

20. EGG-2153

Comparison of Two Options for Supplying Geothermal Energy to the Veterans Administration Medical Center, Marlin, Texas (subcontractor report) 


\begin{tabular}{|c|c|c|}
\hline $\begin{array}{c}\text { GTA } \\
\text { Report No. }\end{array}$ & $\begin{array}{l}\text { EG\&G } \\
\text { Report No: }\end{array}$ & Title \\
\hline 21. & $E G G-2154$ & $\begin{array}{l}\text { Geothermal Utilization at Castle 0aks Subdivi- } \\
\frac{\text { Sion; Castle Rock, Colorado (subcontractor }}{\text { report) }}\end{array}$ \\
\hline 22. & $E G G-2155$ & $\begin{array}{l}\text { Space Heating for Twin Lakes School Near Gallup, } \\
\text { New Mexico (subcontractor report) }\end{array}$ \\
\hline 23. & $E G G-2156$ & $\begin{array}{l}\text { Pumping Tests of Well Campbel1 Et A1. No. 2, } \\
\text { Gila Hot Springs, Grant County New Mexico } \\
\text { (subcontractor report) }\end{array}$ \\
\hline 24 . & EGG-GTH-5739 & $\begin{array}{l}\text { Geothermal Deicing of Highways and Bridge } \\
\text { Structures }\end{array}$ \\
\hline 25. & EGG-GTH-5740 & $\begin{array}{l}\text { Assessment of a Geothermal Application at } \\
\text { Iucson, Arizona }\end{array}$ \\
\hline 26. & EGG-GTH-5741 & Heat Pump Systems for Spring Creek, Montana \\
\hline 27. & EGG-GTH-5779 & Pipe Selection Guide \\
\hline
\end{tabular}




\section{CONTENTS}

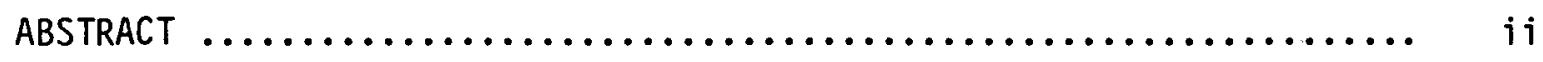

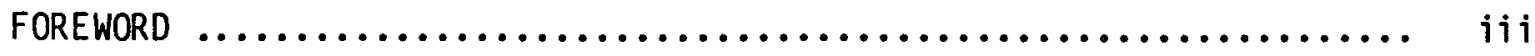

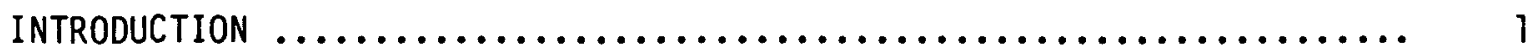

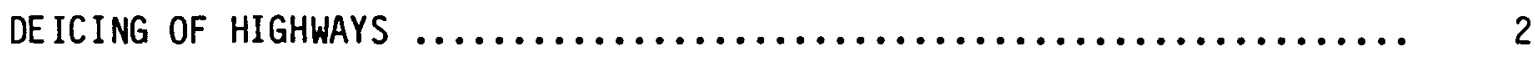

DEICING OF BRIDGE STRUCTURES $\ldots \ldots \ldots \ldots \ldots \ldots \ldots \ldots \ldots \ldots \ldots \ldots \ldots \ldots \ldots \ldots \ldots \ldots \ldots \ldots \ldots$

TABLES

1. Preliminary Un it Cost Estimates for Geothermal Roadway

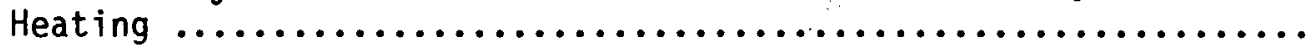

2. Preliminary Unit Cost Estimates for Geothermal Bridge Deck Heating 


\section{IN TRODUCT ION}

A review of the available literature on systems for deicing roadways indicates a lack of empirical data that can be used to confirm assumptions and computations for such projects, especially large projects such as contemplated in the Glenwood $C$ anyon area. It is strongly recommended that the characteristics and availability of an adequate geothermal resource at a reasonable transmission distance be confirmed and that experimental programs be considered to establish or verify design criteria and objectives. In particular, it appears desirable to investigate the feasibility of using an insulating aggregate or other insulating material beneath roadway paving to reduce back losses, thereby reducing the heat load and cost of roadway heating systems. It may also be desirable to investigate the feasibility of innovative designs employing passive heat pipe grids for heating roadway and bridge structures. Designing bridge deck heating systems involves consideration of systems that will not impair the structural integrity of the bridge works, or the roadway surface, in the event of system leakage or failure. Additionally, piping grids cannot generally be placed in aggregate beneath roadway pavement on bridges. Thermal expansion-contraction effects may be greater in heating systems for bridge decks. Systems which might be considered include fluid heating grids embedded in pavement, heat pipe grids in pavement and similar grids located on the underside of bridge decks. Fluid systems embedded in pavement will require circulation of an antifreeze solution in a closed system, heat exchange equipment, and the geothermal supply and disposal systems. 


\section{DEICING OF HIGHWAYS}

Based on information provided by the Colorado Department of Highways and other available data, a preliminary unit cost estimate for geothermally deicing highways in the Glenwood Canyon area was developed. The costs are based on a system for maintaining an ice-free roadway surface when air temperature is $25^{\circ} \mathrm{F}$ and snowfall is at a rate of $1 / 2$ in. per hour. Based on vendor and handbook information it is estimated that a heat rate of 55 to $60 \mathrm{Btu}$ per hour for each square foot of roadway surface will provide an ice-free roadway under these conditions.

Design and spacing of roadway heating grids are functions of the required heat rate, the mean fluid temperature, and the pipe diameter and material. With other conditions fixed, pipe spacing will be reduced as the mean temperature of the fluid or the pipe diameter is reduced. It appears impractical to attempt to attain a fluid exit temperature approaching 35 to $40^{\circ} \mathrm{F}$ due to the required pipe density and the attendant increased head loss and cost.

Available geothermal resource data indicates near-surface geothermal water may be available at temperatures approaching $125^{\circ} \mathrm{F}$. Capital costs for roadway heating are based on a supply temperature of $120^{\circ} \mathrm{F}$, a mean temperature of $100^{\circ} \mathrm{F}$ in the heating grid, and an exit temperature of $80^{\circ} \mathrm{F}$. Based on available information, it is believed that the required heat rate can be supplied by a pipe grid composed of 1-1/4 in. polyethylene pipe.for the spacing of 10 to 12 in., installed beneath a 4-in. concrete roadway. At a heat rate of $55 \mathrm{Btu} / \mathrm{hr} / \mathrm{sq} \mathrm{ft}$, each lane-mile of $11-1 / 2-\mathrm{ft}$ of roadway will require about $170 \mathrm{gpm}$ of hot water to provide the estimated $3.34 \mathrm{x}$ $10 \mathrm{Btu} / \mathrm{hr}$, under design conditions. Similarly, heating of shoulder areas will require a flow of about $115 \mathrm{gpm}$ to provide the estimated $2.3 \mathrm{x}$ $10^{6} \mathrm{Btu} / \mathrm{hr}$ for each mile of $8-\mathrm{ft}$-wide shoulder. It is suggested that a lower heat rate and less dense pipe grid be used for reasons of economy, perhaps a grid composed of $1-1 / 2$ in. polyethylene at a spacing of 15 to 18 in. 
For cost estimating, it is assumed that two to four lanes of highway are contiguous so that supply and discharge lines connected to heating grid circuits are located at approximately 280 - to 140-ft intervals respectively. Supply, discharge, or return piping and headers are assumed to be of asbestos-cement fabrication. Due to the expected high mineral content of the geothermal water, heat exchanger costs are included. These costs are based on a minimum number of heat exchangers, preferably one per well. Stainless steel type-316 plate heat exchangers are specified. However, final material selection and design must be based on the temperature and quality of the geothermal supply. Inclusion of heat exchangers in the system design will likely result in a reduction of the available grid inlettemperature by $10^{\circ} \mathrm{F}$ or more. It is important to obtain higher geothermal temperatures to compensate for heat exchanger losses and to minimize heat exchange costs. If direct circulation of geothermal water is acceptable, the heat exchanger costs should be neglected. In either case, surface disposal of the expended geothermal fluid is assumed.

An adequate bas is for estimating production well depth is not available. A 500-ft production well and pumping from $300 \mathrm{ft}$ is arbitrarily assumed to allow an estimate of pump horsepower and a preliminary cost estimate for the production system. A single well, producing $900 \mathrm{gpm}$, can supply heat for one mile of a four-lane roadway with two 8-ft shoulders under the foregoing conditions. The estimated hor sepower required for pumping is: $75 \mathrm{hp}$ for production, $50 \mathrm{hp}$ for circulation. No credit or penalty is assumed for gravitational effects due to topographical differences between production, utilization, and discharge sites. It should be noted that yearround operation may be necessary to overcome the large thermal inertia of the roadway system and to reduce thermal cycling and attendant expansioncontraction effects, which may damage the roadway under some circumstances. System drainage must be provided to prevent freeze damage in circulating water systems. Closed-circulation systems using an antifreeze solution as a heat transfer medium should be considered for roadway and bridge-deck heating. Table 1 gives preliminary estimates of unit costs of heating sys tems for the roadway heating described. 
TABLE 1. PRELIMINARY UNIT COST ESTIMATES FOR GEOTHERMAL ROADWAY HEATING (\$-Per-Mile Basis)

\begin{tabular}{|c|c|c|c|}
\hline Item & Unit Cost/Mile & \multicolumn{2}{|c|}{$\begin{array}{l}\text { Cost four-lanes, } \\
\text { two shoulders }\end{array}$} \\
\hline We 11 and pump & $\$ 50,000$ & $\$$ & 50,000 \\
\hline Circulation pump & 5,000 & & 5,000 \\
\hline Heat exchanger & 50,000 & & 50,000 \\
\hline Roadway grid(a) & $120,000 /$ l ane & & 480,000 \\
\hline Shoulder grid(a) & $85,000 / 8-f t$ shoulder & & 170,000 \\
\hline Piping, headers $(a)$ & 240,000 & & 240,000 \\
\hline \multirow[t]{2}{*}{ Controls, valves, etc. } & 20,000 (two lanes) & & 40,000 \\
\hline & SUBTOTAL & & $1,035,000$ \\
\hline Design $(10 \%)$ & & & 103,500 \\
\hline \multirow[t]{2}{*}{ Contingency $(10 \%)$} & & & 103,500 \\
\hline & TOTAL & & $1,242,000$ \\
\hline $\begin{array}{l}\text { a. Use of black stee } 1 \\
\text { cement headers and supp } \\
\text { costs for these items }\end{array}$ & $\begin{array}{l}\text { ce of polyethelene grid } \\
\text { return piping will tend } \\
\text { to } 200 \% \text {. }\end{array}$ & $\begin{array}{l}\text { id asb } \\
\text { rease }\end{array}$ & $\begin{array}{l}\text { bestos } \\
\text { e installed }\end{array}$ \\
\hline
\end{tabular}


It appears that installation of heating systems beneath bridge decks may be feasible for bridge designs, that include an enclosed a ir space beneath the deck, with the deck forming the upper surface of the enclosure. Accommodation for adequate drainage in the event of system failure would allow routing distribution piping through the enclosed space. The amount of heat supplied by the dis.tribution pipe will be almost negligible as compared to the heat needed for deicing of the bridge-deck unless the pipe is very large (greater than 10-in. diameter) and the water temperature is quite high (greater than $200^{\circ} \mathrm{F}$ ). Bridge decks will require approximately 100 Btu per hour/per square foot of surface for deicing under the conditions pre$v$ iously specified for roadway deicing. A two-lane, 23-ft-wide bridge deck would require about $2300 \mathrm{Btu} / \mathrm{hr}$ per running foot. At a pipe temperature of $200^{\circ} \mathrm{F}$, a 10-in. pipe could provide only about $800 \mathrm{Btu} / \mathrm{ft}$ to the enclosed air space, assuming the air space is at a temperature of $70^{\circ} \mathrm{F}$.

For a more probable temperature of $120^{\circ} \mathrm{F}$, only about $240 \mathrm{Btu} / \mathrm{hr}$ per foot of 10-in. pipe is available to the air space, or about $10 \%$ of the required heat. If the bottom surface of the air space is well insulated, the heating required will be significantly reduced. The unit cost for bridge deck heating systems seem likely to be two to three times the unit cost for roadway heating, based on the increased unit heat load, the design constraints, and insulation costs which may be near $\$ 0.75$ per square foot of deck for 2 in. of sprayed polyurethane insulation on the lower inside surface of the air space enclosure.

Based on information from the Colorado Department of Highways and other available data, a preliminary unit cost estimate for geothermally deicing $h$ ighway bridge structures also was developed. The estimates are based on systems for maintaining an ice-free roadway surface when air temperature is $25^{\circ} \mathrm{F}$ and snowfall is at a rate of $1 / 2$ in. per hour. A heat rate of 80 Btu per sa $\mathrm{ft}$ is bel ieved to satisfy this heating requirement. Cost estimates are on a per-mile bas is for four-lane bridge decks. A supply temperature of $100^{\circ} \mathrm{F}$, an exit temperature of $55^{\circ} \mathrm{F}$ and a flowrate of $860 \mathrm{gpm}$ are used to develop prel iminary capital cost estimates for two bridge deck deicing 
system designs. Systems considered are: 1) a closed circulation grid with an antifreeze solution as the heat transfer medium, 2) a heat pipe system. System costs are based on the use of black steel pipe at a spacing of 12 in. for each system. Rationale for costing of the geothermal supply system and the closed circulation pipe system is similar to that for costing of roadway deicing systems. Major differences are the pipe material selected and the operating temperatures used in developing. the estimates. "Estimated costs for the heat pipe system include only one supply header, whereas two may be required, depending on the design of the system. Use of a single header will require placement beneath the center line of the bridge deck.

Operating and maintenance cost for heat pipe systems can be expected to approach $25 \%$ less than comparable circulation systems due to reduced power costs for pumping and reduced-ma intenance costs for heat pipes as compared with pipe systems for circulation of thermal fluids.

Table 2 shows estimated capital costs for the above systems together with estimated costs for an optional heat pipe system as of October 30 , 1979.

Due to the significant difference between estimated costs for the two heat pipe systems and the significant design differences, it seems advisable to experimentally determine performance of the two systems before making a final selection. It should be noted that the optional heat pipe system will require approximately twice the geothermal flowrate required by the competing heat pipe design, because the exit temperature of the geothermal fluid is assumed to be about $80^{\circ} \mathrm{F}$. This will result in higher power costs for the optional heat pipe system, along with an increase in required pump horsepower. The lower-cost heat pipe system does not appear to include adequate costs for installation of the heat pipes; this cost may approach several hundred thous and dollars for each mile of four-lane bridge deck. An additional cost of about $\$ 35 / \mathrm{ft}$ should be assessed for transmission-supply pipe in all cases. 
TABLE 2. PRELIMINARY UNIT COST ESTIMATES FOR GEOTHERMAL BRIDGE DECK HEATING (four lanes, $\$$ per mile basis)

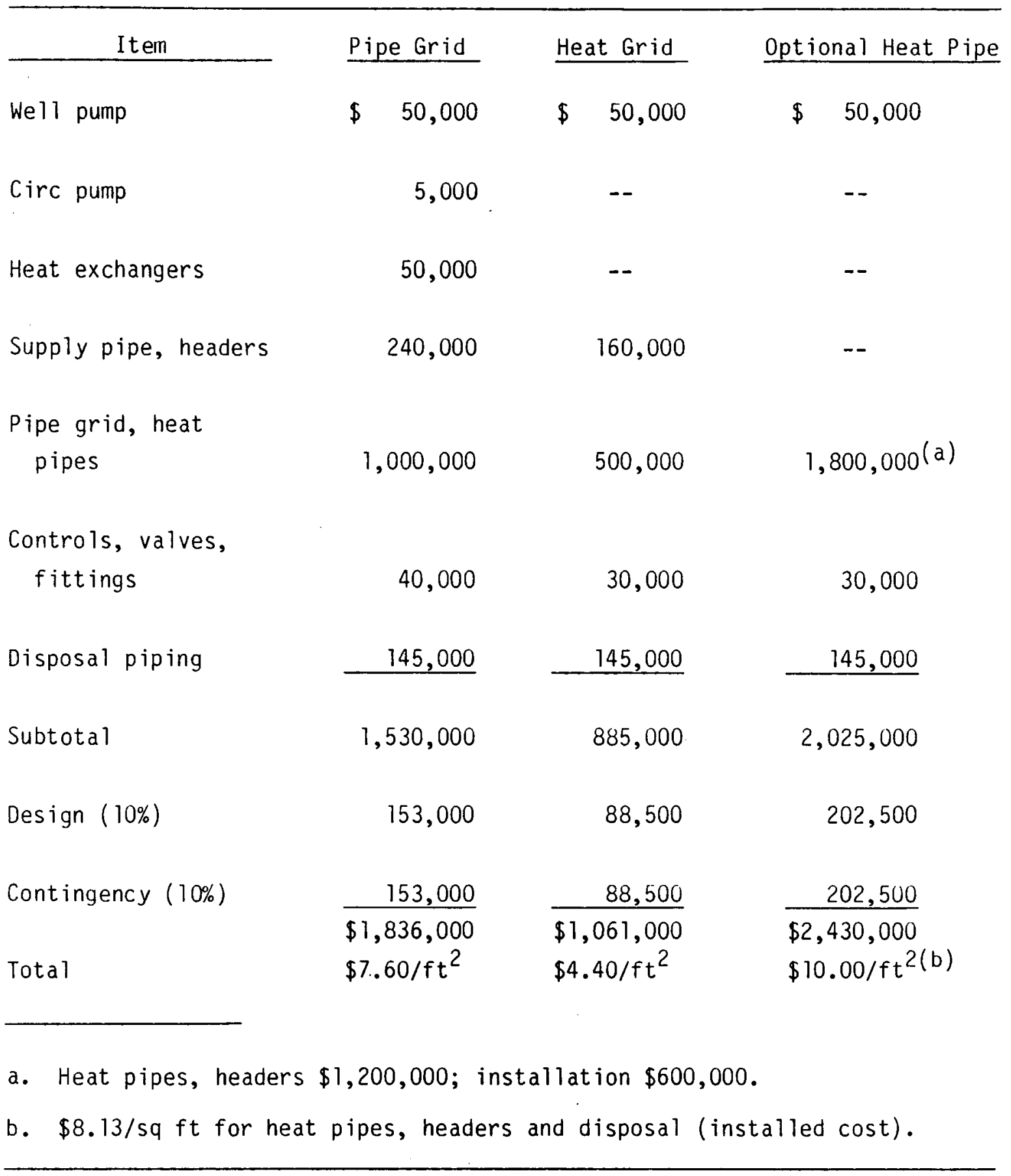

